\title{
The accumulation of selected heavy metals in soils in the vicinity of a busy road
}

\author{
Agata Bartkowiak* \\ UTP University of Science and Technology in Bydgoszcz, Faculty of Agriculture and Biotechnology, Department Biogeochemistry and Soil Science, \\ 6 Bernardyńska St., 85-029 Bydgoszcz, Poland
}

* Agata Bartkowiak, bartkowiak@utp.edu.pl, ORCID iD: http://orcid.org/0000-0003-2535-0085

Received: November 19, 2019

Accepted: April 16, 2020

Associated editor: B. Rutkowska

\section{Keywords}

Heavy metals

Urban soils

Road transport

\begin{abstract}
The paper presents the results of research on the accumulation of selected heavy metals $\mathrm{Zn}, \mathrm{Cu}$, $\mathrm{Pb}, \mathrm{Ni}$ and $\mathrm{Cr}$ ) in soils in the vicinity of a busy road in Bydgoszcz, which is the eighth-largest city in Poland. Soil samples were taken at three depths, at sample points 25, 50, 150 and $175 \mathrm{~m}$ at the side of Jagiellońska Street on the premises of the PKS bus station. The amounts of soil zinc, copper, lead, nickel and chromium were determined by atomic absorption spectrometry after mineralisation in a solution of $\mathrm{HF}$ and $\mathrm{HClO}_{4}$ acids. The total metal contents were ordered as follows: $\mathrm{Zn}>\mathrm{Pb}>\mathrm{Cu}>$ $\mathrm{Cr}>\mathrm{Ni}$. The study confirmed the impact of the traffic-heavy Jagiellońska Street on their concentrations, which decreased with distance from the road. Principal component analysis (PCA) and Pearson linear correlations analysis showed statistically significant positive relationships between the heavy metals and organic carbon. The enrichment factor (EF) confirmed that the surface horizons were significantly enriched in the tested heavy metals.
\end{abstract}

\section{Introduction}

Densely built-up urban agglomerations with a dense street network, dense industry and a diversity of human activities affect the natural environment, which includes the soil. In addition to hydrocarbon compounds, pesticide residues and sulphur, another main factor that threatens soil cleanliness is heavy metals (Niedbała et al., 2010; Czubaszek and Bartoszczuk, 2011; Dzierżanowski and Gawroński, 2011; Athanasopoulou and Kollaros, 2016; Kowalczyk and Szulc, 2017; Kajka and Rutkowska, 2018). One source of toxic gases, dusts and aerosols that contain heavy metals is traffic-heavy roads. The problem of automotive heavy-metal pollution of soils in the vicinity of major thoroughfares is most intense in city districts with high population density and a dense communication network. Here, very large numbers of vehicles move in a relatively small area, and traffic congestion contributes to high emissions (Binggan and Yang, 2010). City soils, which are usually a mosaic of various types and classes, usually present with increased heavymetal contents. This is the result of long-term accumulation in the soil caused by the continuous emission of pollutants, including from traffic (Ptak et al., 2010). A significant proportion of the emitted pollution is deposited on the surface of the ground close to the emission source (Klimowicz and Melke, 2000). Automotive pollution is more dangerous than industrial pollution because it spreads in high concentrations at low altitudes in the immediate vicinity of people (Właśniewski, 2007).

To assess the state of the soil environment, it is enough to know the total forms of heavy metal total content, which determine the potential for each component to enter into circulation in the natural environment (Kabata-Pendias and Pendias, 2001). The total content of heavy metals in soil includes their various forms, which have various mobilities and abilities to transition from solid to soil solution, as well as those that are permanently bound in soil minerals and practically unavailable to plants.

The aim of the study was to assess the contamination of soils in the immediate vicinity of the Bydgoszcz bus station and one of the city's most important streets (Jagiellońska Street) in terms of the following selected heavy metals: zinc (Zn), copper (Cu), lead (Pb), nickel (Ni) and chromium (Cr).

\section{Material and methods}

\subsection{Location of soil sampling}

Bydgoszcz is one of the largest cities in Poland. It is eighth in terms of population, which the latest data estimates at over 350,000 . The city covers just under $176 \mathrm{~km}^{2}$. It is located on the Bydgoszcz Canal, the Brda River and the Vistula River. Bydgoszcz 
is a major centre of industry, trade and logistics, as well as being a road, rail and inland waterways junction. The city is a major communication hub.

The research area is located in the PKS bus station and depot in Bydgoszcz, between the Brda River and one of the city's most important thoroughfares - Jagiellońska Street. The choice of sampling site is no accident; at rush hour in particular, Jagiellońska Street is one of the city's most traffic-heavy roads.

Soil samples were taken from four points located on lawns. A total of 12 representative soil samples were taken. The first two sampling points, named "DW I" and "DW II" (from the abbreviation of the Polish for "station" - dworzec) were located between Jagiellońska Street and the station building. The first was about 25 metres from the street, while the second was about 50 metres away. The two other points ("DW III" and "DW IV") were located between the building of the PKS station and the banks of the Brda River, which flows through Bydgoszcz close to the bus depot. The "DW III" point was located about 150 metres from the street (just behind the bus parking lot), while "DW IV" was near the river bank, about 175 metres from Jagiellońska Street (Fig. 1). In order to determine the relationship between the content of analysed metals and the depth of soil samples taken from each of the sites taken soil samples from different depths at 0-20 $\mathrm{cm}, 40-60 \mathrm{~cm}$ and $90-120 \mathrm{~cm}$.

\subsection{Soil analysis}

In the air-dried soil samples with disturbed structure sieved through a $ø$ 2-mm mesh, the selected physiochemical properties $\mathrm{pH}$ in $\mathrm{H}_{2} \mathrm{O}$ and $\mathrm{pH}$ in $1 \mathrm{M} \mathrm{KCl}$ were measured potentiometrically (PN-ISO 10390: 1997), as was organic carbon $\left(\mathrm{C}_{\text {org }}\right)$ with the Tiurin method (PN-ISO14235 2003) and granulometric composition by laser diffraction using a Mastersizer MS 2000 analyser. In the samples analysed, the total content of zinc, copper, lead, nickel and chromium was measured after mineralisation in a mixture of $\mathrm{HF}+\mathrm{HClO}_{4}$ acids by the Crock and Severson method (1980). The total contents of forms were determined by atomic absorption spectroscopy using a PU 9100X spectrometer (Philips). The

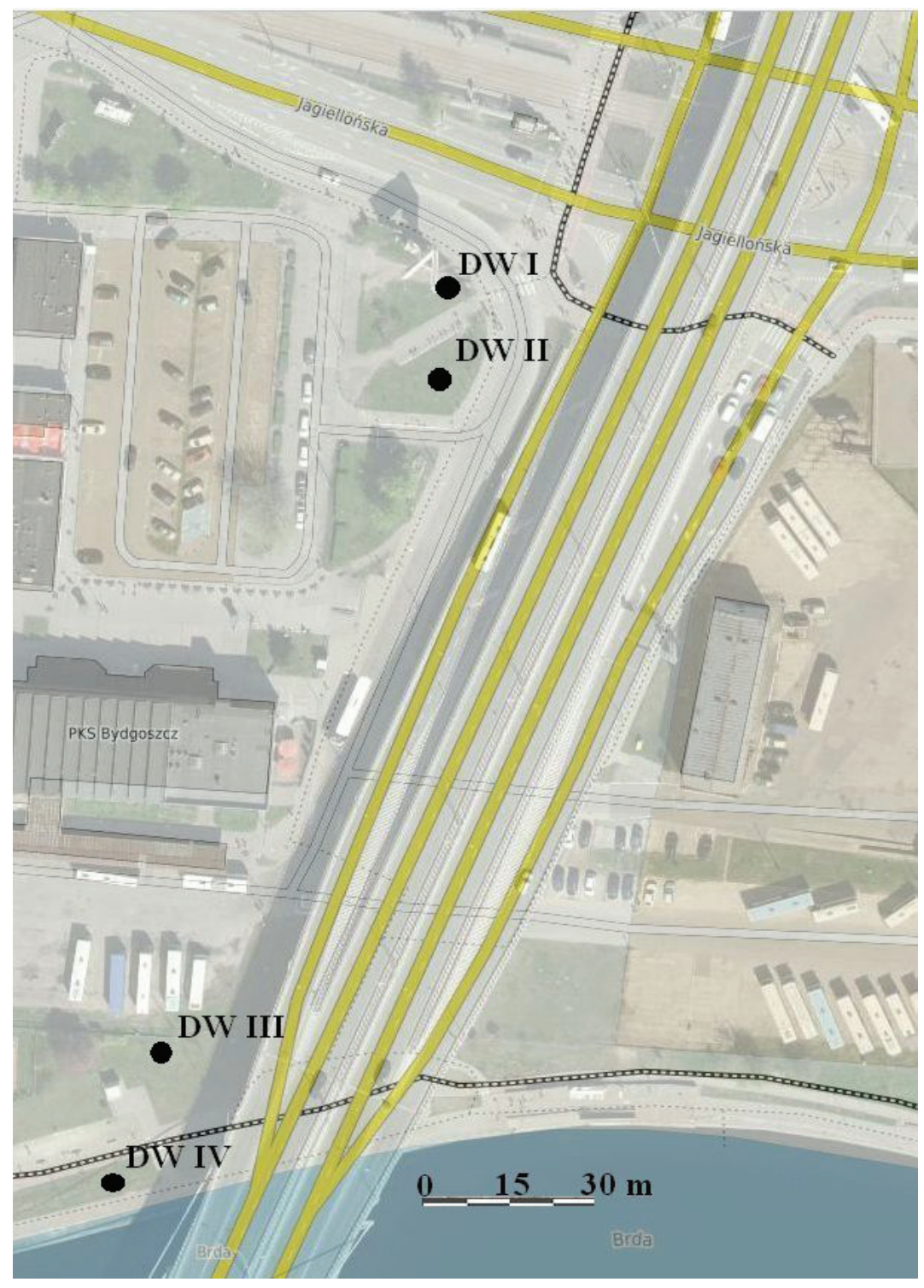

Fig. 1. Localization of study area 
limit of determination for all analysed metals were $0,2 \mathrm{mg} \cdot \mathrm{kg}^{-1}$. To verify the accuracy of the results, the analysis of the certified material Loam Soil No. ERM - CC141 as well as the so-called zero tests were conducted, which were exposed to the identical analytic procedure as the soil samples. Good compatibility between the certified and determined values was obtained. All the determinations were made in triplicates. The results are presented as arithmetic means.

\subsection{Statistical analysis}

Due to the considerable influence of anthropogenic transformations in surface horizons, the soil was also evaluated using the percentage enrichment factor (EF) defined by Zonta et al., (1994) and Loska and Weichula (2003), using

$\% \mathrm{EF}=\mathrm{C}-\mathrm{C}_{\min } /\left(\mathrm{C}_{\max }-\mathrm{C}_{\min }\right) \times 100$

where: $\mathrm{C}$ - mean total concentration in the soil, $\mathrm{C}_{\min }-$ minimum concentration and $\mathrm{C}_{\max }$ - maximum concentration.

Enrichment factor can help in differentiating an anthropogenic source from a natural origin. Five contamination categories are recognised on the basis of the enrichment factor, where $\mathrm{EF}<2$ is deficiency to minimal enrichment, $\mathrm{EF} 2-5$ is moderate enrichment, EF 5-20 is significant enrichment, EF 20-40 is very high enrichment and EF $>40$ is extremely high enrichment (Sutherland 2000).

Principal component analysis (PCA) was performed using a correlation matrix for heavy metals and physicochemical properties. The first two principal components ( $P C 1$ and $P C 2)$ were selected for further interpretation of the results. In addition, Pearson linear correlation coefficients were determined between all analysed variables using the Statistica 13.0 computer program.

\section{Results and discussion}

According to the Polish Soil Classification (2019), the studied soils are Anthropogenic soils, mechanically transformed with artefacts, building debris and technical materials in profiles, with increased content of heavy metals and modified pH (Urbisoils). Table 1 presents selected physical and chemical properties of the analysed soil samples. In most of the tested samples, the clay fraction content ranged from 2.95 to $4.67 \%$, allowing the analysed soils to be classified as sandy loams (PTG 2009). Only the samples from the depths of 40-60 cm and 90-120 cm at DW I deviated, with $8 \%$ and $14.59 \%$ of clay fraction respectively.

Regardless of location, the tested soils were neutral and slightly alkaline (pH in $1 \mathrm{~mol} \mathrm{dm}^{-3} \mathrm{KCl} 7.1-7.62$ ). Hydrolytic acidity was low, ranging from 0.23 to $1.65 \mathrm{cmol} \cdot \mathrm{kg}^{1}$. Similar results for Bydgoszcz soils were obtained by Malczyk et al., (1996) and Różański and Dąbkowska-Naskręt (2011). This is a typical reaction for anthropogenic soils. Soil alkalisation may be the result of changes taking place in this area. There is rubble in the soils, which can increase pH. Additionally, the soil samples were taken from lawns that may have been limed on multiple occasions. The use of $\mathrm{NaCl}$ to remove snow from streets and pavements also contributes to increasing $\mathrm{pH}$.

The organic carbon in the soils varied, ranging from 6.90 to $40.50 \mathrm{~g} \cdot \mathrm{kg}^{1}$. The values of this parameter were highest in the surface-most horizons. The varied organic carbon contents in the soils of lawns, green areas, squares and parks are the result of these soils having been enriched with organic matter by fertilisation with peat, compost and such. This is a characteristic feature of urbanised areas.

Among the analysed heavy metals, the highest values were found for zinc (from 37.21 to $500.88 \mathrm{mg} \cdot \mathrm{kg}^{1}$ ) and the lowest for nickel (from 6.01 to $31.28 \mathrm{mg} \cdot \mathrm{kg}^{1}$ ). The content of other elements was lead from 14.63 to $179.00 \mathrm{mg} \cdot \mathrm{kg}^{1}$, copper from 6.73 to $149.5 \mathrm{mg} \cdot \mathrm{kg}^{1}$ and chromium from 16.54 to $44.60 \mathrm{mg} \cdot \mathrm{kg}^{1}$. The

Table 1

Selected physicochemical properties of soil

\begin{tabular}{|c|c|c|c|c|c|c|c|c|}
\hline \multirow[t]{2}{*}{ Objects } & \multirow{2}{*}{$\begin{array}{l}\text { Depth } \\
\mathrm{cm}\end{array}$} & \multicolumn{2}{|l|}{$\mathrm{pH}$} & \multirow{2}{*}{$\begin{array}{l}\mathrm{Hh} \\
{\mathrm{cmol} \cdot \mathrm{kg}^{-1}}\end{array}$} & \multirow{2}{*}{$\frac{\text { Corg }}{\mathrm{g} \cdot \mathrm{kg}^{-1}}$} & \multicolumn{3}{|c|}{ Fraction\% } \\
\hline & & $\mathrm{H}_{2} \mathrm{O}$ & $\mathrm{KCl}$ & & & Sand & Silt & Clay \\
\hline \multirow[t]{3}{*}{ DW I } & $0-20$ & 7.41 & 7.14 & 0.38 & 19.50 & 62.11 & 34.00 & 3.89 \\
\hline & $40-60$ & 7.84 & 7.37 & 0.23 & 11.55 & 53.91 & 38.09 & 8.00 \\
\hline & $90-120$ & 7.75 & 7.32 & 0.30 & 11.75 & 34.89 & 50.52 & 14.59 \\
\hline \multirow[t]{3}{*}{ DW II } & $0-20$ & 7.70 & 7.54 & 1.65 & 12.65 & 62.72 & 32.68 & 4.67 \\
\hline & $40-60$ & 7.53 & 7.37 & 0.38 & 11.95 & 62.55 & 33.88 & 3.57 \\
\hline & $90-120$ & 7.54 & 7.45 & 0.45 & 8.05 & 62.41 & 33.25 & 4.34 \\
\hline \multirow[t]{3}{*}{ DW III } & $0-20$ & 7.37 & 7.20 & 0.45 & 28.50 & 61.82 & 33.98 & 4.20 \\
\hline & $40-60$ & 8.16 & 7.62 & 0.30 & 8.50 & 67.27 & 28.85 & 3.88 \\
\hline & $90-120$ & 7.73 & 7.62 & 0.53 & 6.90 & 72.46 & 24.49 & 3.05 \\
\hline \multirow[t]{3}{*}{ DW IV } & $0-20$ & 7.24 & 7.10 & 0.45 & 40.50 & 58.14 & 38.92 & 2.95 \\
\hline & $40-60$ & 7.30 & 7.17 & 0.38 & 35.85 & 63.21 & 33.57 & 3.22 \\
\hline & 90-120 & 7.79 & 7.35 & 0.38 & 14.30 & 58.01 & 38.38 & 3.61 \\
\hline
\end{tabular}


metal content in the soil was, in decreasing order of concentration, $\mathrm{Zn}>\mathrm{Pb}>\mathrm{Cu}>\mathrm{Cr}>\mathrm{Ni}$. The highest concentrations of heavy metals were determined in the soil in the point DW IV and the lowest in the point DW III (Table 2). Kajka and Rutkowska (2018) as well as Kowalczyk and Szulc (2017) were obtained, examining the impact on streets and traffic intensity on metal content in Warsaw soils, they found that the concentrations of the studied metals in soils were the highest directly on the edge of the road and significantly decreased with distance from the edge. Similar relationships were noted in own research, but no correlations was found between the depth of sampling and the soil metal content. The content of all analysed metals varied depending on the depth at which soil samples were taken. According to the literature, excessive accumulation of trace elements is limited to about $150 \mathrm{~m}$ either side of the roadway, while beyond this distance values are those of unpolluted areas (Nabuloa et al., 2006; Zehetner et al., 2009; Czubaszek and Bartoszuk, 2011; Dzierżanowski and Gawroński, 2011). In the analysed area, the exception was point DW IV, closest to the river, where the con- centrations of the indicated metals were found to be highest. This sample point was located on a newly created square. It is probable that the fertilisers and peat (perhaps of unknown origin) used to fertilise the area introduced unfavourable quantities of heavy metals into this soil environment.

The enrichment factor is used to differentiate trace metals originating from human activities from those of natural sources. The enrichment factors (EF) calculated for the study area's surface soil horizons indicated very high enrichment in zinc (27\%), nickel (36\%) and chromium (40\%), and extreme contamination in lead (59\%) and copper (43\%) (Fig. 2). The literature states that elevated EF coefficients in urban soils are mainly the result of industrial and automotive emissions (Ali and Malik, 2011; Atiemo et al., 2011; Loska and Wierchuła 2003).

The heavy metals accumulated in the surface soil horizons show high chemical affinity for this horizon's amount of organic matter, consequently slowing its degradation and decreasingbioavailability (Hernandez et al., 2003). Correlation analysis showed statistically significant positive relationships

Table 2

Total content of heavy metals in the soil samples

\begin{tabular}{lllllll}
\hline \multirow{2}{*}{ Objects } & Depth & Zn & $\mathrm{Cu}$ & $\mathrm{Pb}$ & $\mathrm{Ni}$ & $\mathrm{Cr}$ \\
\cline { 2 - 6 } & $\mathrm{cm}$ & $\mathrm{mg} \cdot \mathrm{kg}^{-1}$ & & & & \\
\hline \multirow{2}{*}{ DW I } & $0-20$ & 105.86 & 31.50 & 102.25 & 16.13 & 25.75 \\
\cline { 2 - 6 } & $40-60$ & 99.84 & 47.10 & 51.20 & 26.80 & 40.58 \\
\cline { 2 - 6 } & $90-120$ & 116.34 & 45.10 & 48.66 & 27.78 & 30.78 \\
\hline \multirow{2}{*}{ DW II } & $0-20$ & 108.76 & 21.26 & 51.86 & 12.30 & 21.59 \\
\cline { 2 - 7 } & $40-60$ & 85.975 & 14.33 & 32.92 & 10.83 & 18.46 \\
\hline \multirow{2}{*}{ DW III } & $90-120$ & 86.21 & 18.26 & 38.75 & 12.30 & 19.33 \\
\hline \multirow{2}{*}{ DW IV } & $40-60$ & 86.05 & 13.53 & 27.20 & 9.81 & 17.03 \\
\hline & $90-120$ & 37.21 & 6.73 & 14.63 & 6.01 & 16.61 \\
\hline & $40-60$ & 416.04 & 149.5 & 93.75 & 31.28 & 44.60 \\
\hline
\end{tabular}

$\mathrm{EF} \%$

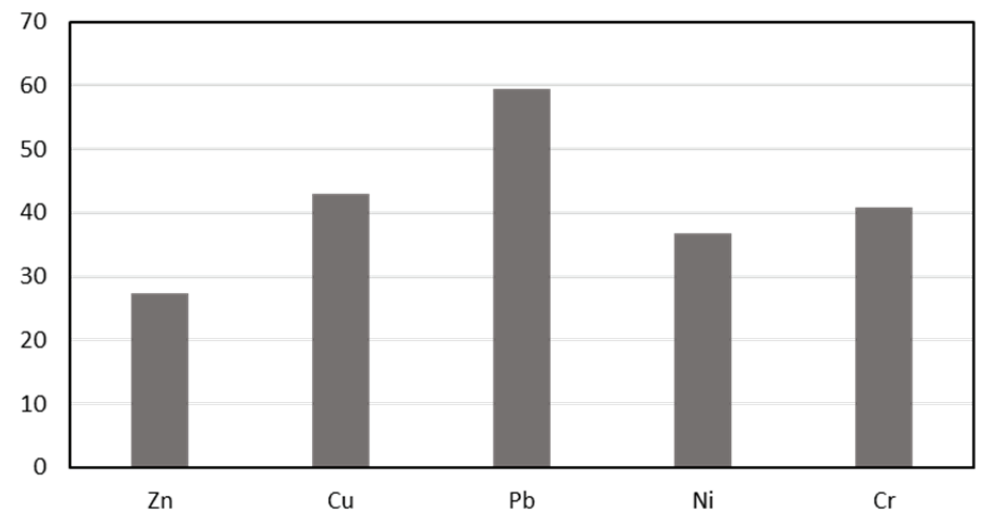

Fig. 2. Enrichment factor 
between the amount of organic carbon and total zinc content $(\mathrm{r}=0.871)$ and copper $(\mathrm{r}=0.613)$ (Table 3). A similar relationship was noted by Gondek and Filipek-Mazur (2003) in studying the binding of heavy metals by humus in soils exposed to traffic pollution. According to the scientific literature, the binding strength of individual heavy metals to organic matter varies. However, humic compounds are important in shaping the binding, activation and migration processes of heavy metals, and this can fundamentally change these elements' mobility in soil. Organic matter is therefore a factor that can both release and immobilise metals in soil. The solubility of heavy metals, and their uptake by plants, are particularly high under acidic soil

Table 3

Pearson's correlation coefficients $(\mathrm{p}<0.05)$ between soil properties and content of heavy metals in soil

\begin{tabular}{lll}
\hline Variable & & \multicolumn{1}{l}{$\mathrm{r}$} \\
\cline { 1 - 2 } Independent & Dependent & \\
\hline $\mathrm{pH} \mathrm{KCl}$ & $\mathrm{Zn}$ & 0.747 \\
\hline $\mathrm{Corg}$ & $\mathrm{Zn}$ & 0.871 \\
\hline $\mathrm{Corg}$ & $\mathrm{Cu}$ & 0.613 \\
\hline $\mathrm{Zn}$ & $\mathrm{Cu}$ & 0.741 \\
\hline $\mathrm{Zn}$ & $\mathrm{Ni}$ & 0.708 \\
\hline $\mathrm{Zn}$ & $\mathrm{Cr}$ & 0.729 \\
\hline $\mathrm{Cu}$ & $\mathrm{Ni}$ & 0.800 \\
\hline $\mathrm{Cu}$ & $\mathrm{Cr}$ & 0.845 \\
\hline $\mathrm{Ni}$ & $\mathrm{Cr}$ & 0.946 \\
\hline
\end{tabular}

Table 4

Values of the two extracted factor loadings for 12 elements

\begin{tabular}{lll}
\hline \multirow{2}{*}{ Elements } & \multicolumn{2}{l}{ Component matrix } \\
\cline { 2 - 3 } & PC1 & PC2 \\
\hline Sand & 0.500 & $\mathbf{- 0 . 8 3 3}$ \\
\hline Silt & -0.623 & $\mathbf{0 . 7 1 5}$ \\
\hline Clay & -0.194 & $\mathbf{0 . 9 4 0}$ \\
\hline $\mathrm{pH} \mathrm{H} \mathrm{H}_{2} \mathrm{O}$ & $\mathbf{0 . 8 3 4}$ & 0.186 \\
\hline $\mathrm{pH} \mathrm{HCl}$ & 0.570 & 0.523 \\
\hline $\mathrm{Hh}$ & 0.283 & -0.197 \\
\hline $\mathrm{Corg}$ & $\mathbf{- 0 . 7 7 4}$ & -0.506 \\
\hline $\mathrm{Zn}$ & $\mathbf{- 0 . 8 2 1}$ & -0.403 \\
\hline $\mathrm{Cu}$ & $\mathbf{- 0 . 8 1 3}$ & -0.169 \\
\hline $\mathrm{Pb}$ & -0.590 & -0.116 \\
\hline $\mathrm{Ni}$ & $\mathbf{- 0 . 9 3 3}$ & 0.240 \\
\hline $\mathrm{Cr}$ & $\mathbf{- 0 . 8 8 0}$ & 0.067 \\
\hline Variation (\%) & 47.54 & 24.68 \\
\hline Eigenvalue & 5.705 & 2.961 \\
\hline
\end{tabular}

Bold value are statisticaly signification conditions. Correlation analysis found a statistically significant positive relationship between the concentration of $\mathrm{H}^{+}$cations and zinc content (0.747). The high Pearson coefficients found between the tested heavy metals (Table 3 ) indicate a common source of soil contamination. These heavy metals are considered typical of brake-pad wear, and are present in tyre rubber (Lin et al., 2005).

The principal component analysis (PCA) identified two main components ( $P C 1$ and $P C 2$ ) that explained $72.23 \%$ of the total change in variance (Table 4). Component 1 (PC1) was responsible for $47.55 \%$ of all variable component elements and correlated strongly with active acidity (0.834), organic carbon (0.774), total zinc (0.821), copper (0.813), nickel (0.933) and chromium (0.880). Component 2 (PC2), which explained $24.68 \%$ of the total variance, was associated with the fractions of sand (0.833), silt (0.715) and clay (0.940). The graph (Fig. 3) shows that the vectors of factors representing the total content of zinc, copper, nickel, chromium and organic carbon show the largest negative linear relationships, meaning they can be grouped into part of the first principal component. The longer the vector inside the circle, the greater the correlation with the component. The second component was most heavily influenced by the contents of the sand, silt and clay fractions. On analysis of the distribution of the soil's basic properties and the quantity of metals extracted from it in the coordinate factor graph, it can be concluded that the total contents of zinc and copper correlated most strongly with organic carbon content. The principal component analysis also confirmed the correlations between the metals tested. The figure shows that the zinc, copper and lead contents correlate negatively with the soil reaction expressed as pH (Fig. 3).

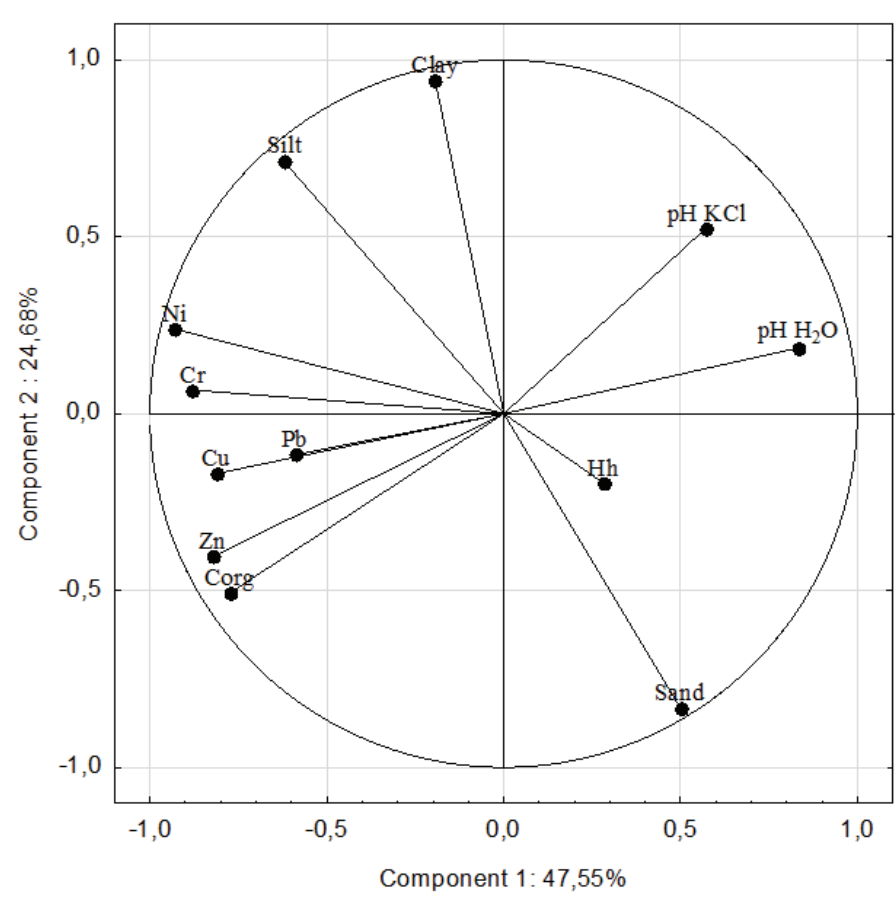

Fig. 3. Configuration of variables in the system of the first two axes PC1 and PC2 of principal components 


\section{Conclusions}

1. The contents of the analysed heavy metals were in the order: $\mathrm{Zn}>\mathrm{Pb}>\mathrm{Cu}>\mathrm{Cr}>\mathrm{Ni}$.

2. The enrichment factor (EF) for the surface horizons of the analysed soils indicates "very high" and "extremely high" enrichment with the metals tested.

3. Statistically significant positive correlations between the examined metals indicated a common source of soil contamination.

4. Principal component analysis (PCA) and Pearson linear correlations analysis showed statistically significant positive relationships between the heavy metals and organic carbon content in soil.

5. The research confirmed the impact of traffic-heavy roads on the total content of zinc, lead, copper, nickel and chromium in soils in the road's immediate vicinity.

\section{References}

Ali, S.M., Malik, R.N., 2011. Spatial distribution of metals in top soils of Islamabad City, Pakistan. Environmental Monitoring and Assessment 172, 1-16. http://doi.org/10.1016/S2248-9697(03)00223-7

Athanasopoulou, A., Kollaros, G., 2016. Heavy metal contamination of soil due to road traffic. American Journal of Engineering Research 5(12), 354-363.

Atiemo, M.S., Ofosu, G.F., Mensah, H.K., Tutu, A.O., Linda Palm, N.D.M., Blankson, S.A., 2011. Contamination Assessment of Heavy Metals in Road Dust from Selected Roads in Accra, Ghana. Research Journal of Environmental and Earth Sciences 3(5), 473-480.

Binggan, W., Yang, L., 2010. A review of heavy metal contaminations in urban soils, urban road dusts and agricultural soils from China. Microchemical Journal 94, 99-107. http://doi.org/10.1016/ j.microc.2009.09.014

Crock, J.G., Severson, R., 1980. Four reference soil and rock samples for measuring element availability in the western energy regions. Geochem Survey Circular 841, 1-16.

Czubaszek, R., Bartoszuk, K., 2011. Content of selected heavy metals in soils in accordance with its distance from the street and land use. Civil and Environmental Engineering - Budownictwo i Inżynieria Środowiska 2, 27-34.

Dzierżanowski, K., Gawroński, S.W., 2011. Analysis of heavy metals content in soil and dandelion leaves in the vicinity of a bus urban street using a handheld XRF spectrometer. Environmental Protection and Natural Resources 50, 202-211.

Gondek, K., Filipek-Mazur, B., 2003. Heavy metal bonding by the soil humus in the soils liable to traffic pollution. Acta Agrophysica 2(4), 759-770.

Hernandez, L., Probst, A., Proust, J.L., Ulrich, E., 2003. Heavy metal distribution in some French forest soils: evidence for atmospheric contamination. Science of the Total Environment 312(1-3), 195-219. http://doi.org/10.1016/S2248-9697(03)00223-7

Kabata-Pendias, A., Pendias, H., 2011. Trace Elements in Soils and Plants. 3re.ed., CRC Press.
Kajka, K., Rutkowska, B., 2018. Acumulation of selected heavy metals in soli and common dandelion (Taraxacum officinale) near a road with high traffic intensity. Roczniki Gleboznawcze - Soil Science Annual 69(1), 11-16. http://doi.org/10.2478/ssa-2018-0002

Klimowicz, Z., Melke, J., 2000. The content of heavy metals in soils in the vicinity of traffic roads using chosen stretches of road as examples. Roczniki Gleboznawcze - Soil Science Annual 51(3/4), 37-46.

Kowalczyk, A., Szulc, W., 2017. Effect of traffic routes on the trace element concentration in plants in the Warsaw agglomeration. Roczniki Gleboznawcze - Soil Science Annual 68(2), 93-98. http://doi.org/10.1515/ ssa-2017-0011

Loska, K., Wiechuła, D., 2003. Application of principal component analysis for the estimation of source of heavy metal contamination in surface sediments from the Rybnik Reservoir. Chemosphere 51, 723-733. http://doi.org/10.1016/S0045-6535(03)00187

Nabuloa, G., Oryem-Origa, H., Diamond, M., 2006. Assessment of lead, cadmium, and zinc contamination of roadside soils, surface films, and vegetables in Kampala city, Uganda. Environmental Research 101, 42-52. http://doi.org/10.1016/j.envres.2005.12.016

Niedbała, M., Solińska, B., Król, K., 2010. Trace elements as pollutants of urban soils of Lodz. Zeszyty Naukowe Politechniki Łódzkiej. Chemia Spożywcza i Biotechnologia 74, 30-38.

Malczyk, P., Kędzia, W., Nowak, M., 1996. Heavy metals in soil of the Bydgoszcz City. Roczniki Gleboznawcze - Soil Science Annual 67(3/4), 195-2002.

PN-ISO 10390, 1997. Chemical and Agricultural Analysis - Determining soil pH. Polish Standards Committee, Warszawa

PN-ISO14235, 2003. Chemical and Agricultural Analysis - Soil quality - determining the content of organic carbon by oxidation of potassium dichromate (VI) in the environment of sulphuric acid (VI). Polish Standards Committee, Warsaw.

Polish Soil Classification $6^{\text {th }}$ edition (Systematyka Gleb Polski Wyd. 6), 2019. Polskie Towarzystwo Gleboznawcze, Komisja Genezy, Klasyfikacji i Kartografii Gleb, UWP Wrocław-Warszawa.

Ptak, A., Bartmiński, P., Dębicki, R., 2010. Influence of public transport on the content of chosen heavy metals in soils neighbouring Lublin streets. Proceedings of EC Opole 4(1), 167-171.

PTG 2009. Particle size distribution and textural classes of soil and mineral materials - classification of Polish Society of Soil Sciences 2008. Roczniki Gleboznawcze - Soil Science Annual 60(2), 5-16.

Różański, Sz., Dąbkowska-Naskręt, H., 2011. Spatial and profile distribution of mercury in urbanozems of Bydgoszcz city. Environmental Protection and Natural Resources - Ochrona Środowiska i Zasobów Naturalnych 49, 193-201.

Sutherland, R.A., 2000. Bed sediment associated trace metals in an urban stream. Oaho. Hawaii. Environmental Geology 39, 611-627.

Właśniewski, S., 2007. Effect of automotive traffic emissions on the content of heavy metals in soils located close to the national road Rzeszow-Łańcut. Advances of Agricultural Sciences Problem Issues 520, 189-200.

Zonta, R., Zaggia, L., Argrse, E., 1994. Heavy metal and grain size distributions in estuarine shallow water sediments of the Cona Marsh (Venice Lagoon. Italy). Science of the Total Environment 151, 19-28.

Zehetner, F., Rosenfellner, U., Mentler, A., Gerzabek, M.H., 2009. Distribution of road salt residues, heavy metals and polycyclic aromatic hydrocarbons across a highway-forest interface. Water Air Soil Pollution 198, 125-132. http://doi.org/10.1007s11270-008-9837-8 
Akumulacja wybranych metali ciężkich w glebach w sąsiedztwie ulicy o dużym natężeniu ruchu

\section{Słowa kluczowe}

Metale ciężkie

Gleby miejskie

Transport uliczny

\section{Streszczenie}

W pracy przedstawiono wyniki badań dotyczące akumulacji całkowitych zawartości wybranych metali ciężkich ( $\mathrm{Zn}, \mathrm{Cu}, \mathrm{Pb}$, Ni i $\mathrm{Cr}$ ) w glebach w sąsiedztwie ulicy o dużym natężeniu ruchu w ósmym co do wielkości mieście Polski - Bydgoszczy. Próbki glebowe pobrano z trzech głębokości, z punktów badawczych oddalonych o 25, 50, 150 i 175 m od krawędzi ulicy Jagiellońskiej na terenie dworca PKS. Ilości cynku, miedzi, ołowiu, niklu i chromu w glebach oznaczono metodą absorpcyjnej spektrometrii atomowej po mineralizacji w mieszaninie kwasów $\mathrm{HF}$ i $\mathrm{HClO}_{4}$.

Zawartość całkowita metali kształtowała się w następujący sposób $\mathrm{Zn}>\mathrm{Pb}>\mathrm{Cu}>\mathrm{Cr}>\mathrm{Ni}$. Badania potwierdziły wpływ obciążonej ruchem ulicy Jagiellońskiej na ich zwartość, która malała wraz $\mathrm{z}$ odległością od drogi. Przeprowadzone analizy głównych składowych $(P C A)$ oraz korelacji liniowych Pearsona wykazały istotne statystyczne dodatnie zależności pomiędzy metalami ciężkimi a węglem organicznym. Wskaźnik wzbogacenia (EF) potwierdził znaczne wzbogacenie poziomów powierzchniowych w badane metale ciężkie. 